\title{
A POLÍTICA DO “ROSTO SEVERINO” EM O HOMEM QUE VIROU SUCO, DE JOÃO BATISTA DE ANDRADE*
}

\author{
Alessandra Soares Brandão** \\ Júlio César Alves da Luz***
}

\begin{abstract}
Resumo: Este trabalho tem por objeto uma leitura de O Homem que virou suco (João Batista de Andrade, 1979), a fim de problematizar o viés miserabilista, vitimizante, que rebaixa a figura do imigrante nordestino, pensando-a a partir de uma política do rosto que busque um outro traçado que escape aos traços engessados de uma imagem sua estereotipada, que desfaça os contornos aprisionadores que encerram essa figura na moldura de um retrato despotencializador, historicamente estigmatizada nas telas do cinema e da televisão.
\end{abstract}

Palavras-chave: Rosto. Estereótipo. Cinema brasileiro. Imigrante nordestino.

Eu descobri que o meu rosto e a minha voz eram armas. O sistema tinha capital, dinheiro, repressão. Eu tinha uma cara de José Dumont.

José Dumont. Em entrevista.

O Homem que virou suco (João Batista de Andrade, 1979) narra a história de Deraldo, poeta popular paraibano que procura sobreviver em São Paulo com a venda de seus folhetos de cordel. Confundido, porém, com José Severino, operário que assassinara o patrão, Deraldo é perseguido pela polícia, da qual foge num caminho que o força a percorrer espaços e a se submeter a situações que expõem a discriminação violenta e a exploração brutal, reificadora, da mão-de-obra imigrante numa metrópole tão hostil à presença "nortista". Cruzando, assim, as histórias desses dois homens ambos interpretados por José Dumont - por conta da confusão de seus rostos, o filme questiona a imagem historicamente cristalizada que os reduz às linhas estereotipadas de uma vacuidade identitária desenhada nos traços que permitiriam classificá-los como do "tipo nordestino". Uma imagem homogeneizadora que define e lhes dá um rosto comum, cujas formas que o identificam, encarnadas na figura do ator paraibano, expressam-se nesses rostos que se confundem - mais do que por uma eventual semelhança fisionômica - pela sua "feição nordestina".

\footnotetext{
*Este artigo é um desdobramento do trabalho de pesquisa de mestrado no Programa de Pós-Graduação em Ciências da Linguagem da Universidade do Sul de Santa Catarina, defendido em novembro de 2013, cujo objeto procurou problematizar a figura do imigrante nordestino na ficção audiovisual brasileira a partir dos personagens protagonizados pelo ator José Dumont em O Homem que virou suco (João Batista de Andrade, 1979) e em Morte e vida severina (Walter Avancini, 1981). Cf. LUZ, Júlio C. A. da. Rostos severinos: figuras do homem ordinário na ficção audiovisual brasileira. 2013. Dissertação (Mestrado em Ciências da Linguagem). Universidade do Sul de Santa Catarina, Florianópolis, 2013.

** Doutora em Letras pela Universidade Federal de Santa Catarina. Professora do Programa de PósGraduação em Ciências da Linguagem da Universidade do Sul de Santa Catarina. E-mail: alessandra.b73@gmail.com

*** Doutorando no Programa de Pós-Graduação em Ciências da Linguagem da Universidade do Sul de Santa Catarina. E-mail: julio_daluz@hotmail.com.
} 
Numa alusão à acepção generalizante que no poema de João Cabral de Melo Neto (Morte e vida severina, 1955) torna-se metáfora para designar o gênero de vida que marca o elemento humano do sertão nordestino, as linhas que compõem o rosto que o identifica enquadram-no no que poderíamos denominar um "rosto severino"1. O nome genérico, por derivação imprópria a partir de um prenome bastante comum na região, expressa igualmente o sentido generalizante da operação que produz o rosto dessas vidas irmanadas numa condição comum: a vida severina. São rostos reconhecidos pela visibilidade alcançada no cinema e nas mídias, sob um ângulo, porém, frequentemente reducionista, capturados na moldura de uma imagem com o tempo cristalizada, reprodutora de uma ótica sobretudo vitimizante, isto é, a imagem de uma massa de deserdados condenados pelas condições sob as quais vivem.

A perspectiva despotencializadora que enquadra assim a figura do imigrante e a expõe nessas linhas tão duras da esquemática representação em que aparece nas telas reproduz os reducionismos que a abordagem dos interesses midiáticos impõem, de modo geral, à figuração do homem ordinário. Um olhar enviesado que se fecha ao figurá-lo num meio marcado pela violência quotidiana, a miséria irremediável e as tragédias inevitáveis, e que resulta do interesse que a vida ordinária suscita tão-somente quando este "ordinário" é perturbado por algo "extraordinário", quando essa vida é vitimada por acontecimentos trágicos ou objeto de interesse para qualquer coisa que sobressaia de exótico ou curioso. Uma visão um tanto problemática que não é senão o custo maior de uma ampla visibilidade sua que se alargou nas últimas décadas, interesse crescente cujo ônus recai no engessamento de um olhar alienado do mundo do outro, que o figura - como observa César Guimarães em seus estudos acerca da vida ordinária na produção documentária brasileira - sob o duplo signo do miserabilismo e da violência espetacularizada. É o ângulo de quem olha de fora, a percepção unilateral nas relações entre aquele que filma e quem é filmado - que produz e acaba cristalizando uma imagem distorcida do universo do outro, que "concebe a representação do outro de classe", segundo Guimarães, "como um jogo excessivamente polarizado, no qual o realizador exerce quase sempre uma força desigual e preponderante sobre o sujeito filmado" (2010, p. 183). A unilateralidade dessa relação vertical aprofunda as diferenças que aí se interpõem, resultando numa visão despotencializadora do mundo desse "outro de classe" - como o denominava Jean-Claude Bernardet (2003) -, já que "nele identifica somente o que recai sob a rubrica do representado, o resultado da operação da representação, o fato, o condicionado, o estado cristalizado e acabado" (GUIMARÃES, 2010, p. 191-192).

$\mathrm{Na}$ contracorrente, contudo, da reiterada leitura miserabilista, vitimizante, sob a qual é frequentemente retratada, em particular, a figura do imigrante nordestino, $O$ Homem que virou suco coloca em questão a imagem estereotipada segundo a qual nos são exibidos seus rostos severinos. Ao cruzar as histórias de Deraldo e José Severino

\footnotetext{
${ }^{1}$ Num sentido próximo, por ocasião de uma das apresentações do Programa Abertura, Glauber Rocha se referia a Severino como "a face do povo". O programa era exibido, no contexto da redemocratização do país, às noites de domingo, na Rede Tupi de Televisão, e contava, sob a direção de Fernando Barbosa Lima, com a participação de personalidades dos meios intelectual, artístico e político. Na sua apresentação, Glauber atacava, então, o cinema nacional, acusando-o de reacionário, esquecido de Severino, "a face do povo", segundo o cineasta.
} 
pela confusão de seus rostos, o filme problematiza precisamente os contornos que os aprisionam nos presumíveis traços identificadores que os assinalariam, discriminandoos e os rebaixando à casta do "tipo severino". Isso porque é justamente tal confusão que instala o conflito a partir do qual acompanhamos o personagem, perseguido pela política porque identificado como sendo o operário homicida, mas identificado justamente por conta de seu "rosto severino", um rosto comum que o remete como mais um à massa de imigrantes que fluíam, na época, para São Paulo, uma mão-de-obra relegada às piores condições de trabalho, segregada em regiões periféricas.

Confundindo, de início, o próprio espectador, o filme apresenta, em poucos minutos, entre as três primeiras sequências, os dois personagens. Começo surpreendente, que salta do contexto de um evento solene - no qual vemos José Severino da Silva assassinar seu patrão com uma peixeira no momento em que recebia dele o prêmio de "Operário Padrão" - desviando-se, em seguida, para um outro espaço, um espaço qualquer da periferia paulistana, onde entramos num dos barracos em meio ao amontoado babélico daqueles toscos casebres, encontrando ali um homem que dorme muito mal instalado e cujo rosto, de perfil, é idêntico ao do operário assassino da primeira sequência. Ocorre, porém, que já não se trata de José Severino, mas de um outro homem, que logo descobriremos ser Deraldo, poeta popular em vez de operário, dois homens completamente diferentes, que ignoraram a existência um do outro, embora fisionomicamente iguais.

O filme opera, assim, de entrada, uma bifurcação fundamental, deixando um personagem cuja história fica suspensa, adiando o esclarecimento para a situação em que se envolve, e salta para outro, redirecionando a narrativa. Contudo, há uma intersecção, um ponto em que seus caminhos se atravessam, quando se desvela o porquê que cruza suas histórias e que constitui a ideia central em torno da qual a trama do filme se desenvolve, revelando-o poucas sequências depois, no momento em que Deraldo, após o trabalho de venda de seus folhetos na rua, retorna à noite para casa e é avisado por um menino que a polícia o procura. O motivo está estampado na primeira página do jornal que o garoto lhe entrega, onde se destaca a imagem do rosto do operário que cometera o crime, um rosto idêntico ao seu. Como que diante de uma imagem refletida - após enquadramento da câmera em plano detalhe sobre o jornal, onde vemos a mão do personagem que o segura e a imagem meio esmaecida de José Severino -, Deraldo, então, comenta: "Puta que pariu, rapaz! É minha cara mesmo!"

O filme produz, aqui, como em outros tantos momentos assinalados sobretudo pelas relações do duplo que a obra coloca em questão, uma "imagem especular", uma das formas da "imagem-cristal" que, na taxionomia desenvolvida por Gilles Deleuze em seus estudos dedicados ao cinema, representa a culminância do processo que constituíra a "imagem-tempo", aquela que caracteriza, segundo o autor, o cinema dito moderno, por oposição à "imagem-movimento" que lhe precedera, predominando no cinema clássico. Como explica o filósofo francês, a imagem-cristal é aquela que nos dá uma imagem direta do tempo, "um pouco de tempo em estado puro", pois o que o cristal nos revela ou nos faz ver, observa Deleuze numa concepção bergsoniana, "é o fundamento oculto do tempo, quer dizer, sua diferenciação em dois jorros, o dos presentes que passam e o dos passados que se conservam”. (2007, p. 121). Trata-se de uma imagem 
bifacial, sendo o presente uma imagem atual e o passado contemporâneo uma imagem virtual, os dois jorros em que o tempo se desdobra, indiscerníveis, em diferentes relações de troca, como no espelho, no qual as trocas cristalinas mergulham os personagens em virtualidades que se aprofundam: "a imagem especular", diz o autor, "é virtual em relação à personagem atual que o espelho capta, mas é atual no espelho que nada mais deixa ao personagem além de uma mera virtualidade, repelindo-a para o extra-campo" (idem, p. 89).

Quando Deraldo vê a imagem do rosto de José Severino no jornal, ele, nesse sentido, se vê, uma imagem espelhada que marca o encontro dos personagens, o ponto em que suas vidas se cruzam. É o reflexo de seu rosto que o personagem tem diante de si, num sentido praticamente literal expresso por uma construção imagética que manteve, na foto do jornal, o tamanho do rosto, sem os óculos, inclusive, que José Severino deveria usar, num enquadramento de plano detalhe e posicionamento de câmera que nos fazem parecer que o jornal/espelho, ao invés de exibir um rosto impresso, revelasse um rosto refletido. Os personagens são certamente dois homens diferentes, porém, ao mesmo tempo, é o mesmo homem que se desdobra em dois personagens, são dois rostos iguais como imagens refletidas de vidas que se trocam no acidente pelo qual acabam se atravessando. Mas também, mais que isso, é uma imagem que se multiplica, como numa casa de espelhos que propagasse em reflexos inumeráveis o mesmo rosto, os rostos severinos de uma multidão com um só rosto, um único traçado que os classifica e identifica.

Ora, o rosto, como observam Gilles Deleuze e Félix Guattari (2007), é produzido socialmente por agenciamentos de poder particulares, uma operação disposta a uma estratégia de poder, problema que envolve uma política. Porém, embora produzido na humanidade, o rosto não é uma necessidade humana em geral. O rosto não é um universal, advertem os autores; pelo contrário, trata-se de algo bastante particular, isto é, o homem branco: "o rosto é o Cristo". Uma ideia particular, mas que acabou adquirindo e passou a exercer uma função mais geral: dupla função de biunivocização e binarização.

Em linhas gerais, explicam Deleuze e Guattari, os rostos nascem apenas a partir do desencadeamento, sob determinado agenciamento de poder, do que eles denominam "máquina abstrata de rostidade", que os produzirá formando, primeiramente, combinações de unidades elementares - rostos em correlação biunívoca um com o outro, sempre em termos de "um x ou um y" - partir das quais surgem e se transformam os rostos concretos individuados. Por outro lado, no entanto, a máquina deve também realizar uma resposta seletiva aos rostos concretos que ela julga segundo uma correlação binária do tipo "sim-não", rejeitando, até certo nível de escolha, os rostos nãoconformes ou que apresentem ares suspeitos, produzindo, antes, "desvios padrão de desviança para tudo aquilo que escapa às correlações biunívocas", e instaurando, por conseguinte, "relações binárias entre o que é aceito em uma primeira escolha e o que não é tolerado em uma segunda, em uma terceira, etc." (DELEUZE; GUATTARI, 2007, p. 44-45). Ninguém fica sem rosto, a máquina, primeiro, captura a todos, até mesmo os desvios, inscreve-os "no conjunto de seu quadriculado", para só então, depois de inclusos, excluir os rostos não-conformes. E, como observam os autores, dado que o 
rosto é o Cristo, as primeiras desvianças certamente serão raciais: o negro, o índio, o asiático ou, no caso de que tratamos aqui, o nordestino, traçados não-conformes, como os que desenham o que denominamos o "rosto severino", uma imagem racista que representa uma desviança, identificável nessa condição, em relação ao homem branco. Afinal, é sobre essa base, para os dois filósofos, e não segundo a perspectiva da exclusão do outro, que se fundamenta o racismo europeu:

\footnotetext{
O racismo procede por determinação das variações de desvianças, em função do rosto Homem branco que pretende integrar em ondas cada vez mais excêntricas e retardadas os traços que não são conformes, ora para tolerá-los em determinado lugar e em determinadas condições, em certo gueto, ora para apagá-los no muro que jamais suporta a alteridade (é um judeu, é um árabe, é um negro, é um louco..., etc.) (idem, p. 45).
}

Não há, portanto, pessoas de fora, mas tão-somente pessoas que deveriam ser como o homem branco europeu, mas que não o são, representando, assim, desvianças que a máquina abstrata de rostidade determina. Não há nenhum fundamento biológico que dê razão a uma suposta diferenciação de raças na espécie humana, motivo pelo qual frustraram sempre os esforços, com pretensões científicas inclusive, das mais variadas teorias raciais, a exemplo do arianismo nazista. Sem fundamento algum, o que, com efeito, alimenta o racismo é precisamente essa operação maquínica de que falam Deleuze e Guattari, num processo pelo qual o ser humano é catalogado, então, no quadro de uma classificação em raças e, nessa condição, identificado, uma taxinomia social e historicamente fabulada, que o diferencia no quanto se afasta mais ou menos do homem branco como centro e o remete a um conjunto pelos pretensos traços que o reúnem em um grupo, dependendo do contexto, mais ou menos discriminado.

Uma única marca, em suma, com efeito discrimina os grupos humanos, como se condenados a trazerem no rosto este estigma de Caim: o crime de não serem como o branco europeu. Razão pela qual, no filme que analisamos, antes que a falta de documentos comprometa Deraldo, é já o seu rosto - um "rosto severino" - que o compromete. Sem documentos que o permitam provar, o personagem não poderá, quando confrontado com policiais, convencer que ele, Deraldo José da Silva, não matara ninguém, que o operário assassino, José Severino da Silva, é outra pessoa. É o quanto basta para que seja exposto à arbitrariedade policial, lançando-o a uma situação que não se resolverá, entretanto, simplesmente com a conquista de um documento de identidade. Pelo contrário, aquele homem já se encontra, em tal situação, muito bem identificado: "cara de nordestino", isto é, capturado pela esfera do poder sob os traços não-conformes que o definem enquanto um rosto severino, um imigrante, sem documentos, morador num barraco da periferia de São Paulo.

Deraldo surge, antes de tudo, identificado nos traços de um rosto severino comum, expressão de uma condição severina compartilhada, que é a condição - para recorrer um conceito de Giorgio Agamben (2010) - da "vida nua", a vida reduzida ao seu mínimo biológico, a vida natural que interessa aos mecanismos e cálculos do Estado biopolítico. É a condição de todos aqueles que, de fato, se não de direito, encontram-se excluídos da política, consoante a cisão biopolítica de que fala o filósofo italiano ao observar a ambivalência do conceito de povo no Ocidente, termo que designa, ao 
mesmo tempo, tanto o sujeito político constitutivo, quanto os miseráveis, os deserdados, os excluídos. É a vida de homens populares como Deraldo, homens que não são, porém, daquele Povo - que Agamben grafa assim com "p" maiúsculo para diferenciá-lo de seu sentido oposto - como sujeito político protegido pelo ordenamento jurídico de um Estado, mas daquele povo despojado de direito, reduzido à vida nua e que, portanto, como o personagem do filme, vive completamente rejeitado à margem, em espaços miseráveis e atravessados pela violência.

Essa é a razão pela qual a força repressora da polícia pode invadir arbitrariamente os barracos no morro onde Deraldo vive, em meio a uma massa de tantos outros imigrantes, no abandono de um espaço marginalizado. E isso justamente por conta da confusão de seu rosto. Assim, quando o personagem procura explicar aos policiais que lhe dão voz de prisão que ele e o operário foragido são realmente parecidos, mas que o nome, por outro lado, como lhe pareceria bastar para provar, é diferente, um dos policiais exprime precisamente o que de fato instaura o problema que o envolve: "É, mas tudo esses pau-de-arara é Silva". Não são apenas rostos, portanto, mas também nomes que se confundem, são todos "pau-de-arara", são todos "Silva", todos estigmatizados pelos traços que parecem "identificar" uma categoria de excluídos, os rostos severinos de todos aqueles que são "iguais em tudo e na sina", conforme os versos de João Cabral de Melo Neto (2007). O filme, então, que se desvia de José Severino para falar de Deraldo, poderia igualmente ter se desviado deles para tratar de qualquer outro Silva, ou mesmo ter escolhido, em meio à massa de tantos imigrantes, um outro qualquer rosto severino, um outro homem ou mulher qualquer na mesma condição. Algo de certo modo próximo, como lembra Romildo Sant'Anna, a alguns filmes clássicos do Neorrealismo italiano, como em Ladrões de Bicicletas (Vittorio De Sica, 1948), "em que a câmera passeia sobre a multidão, e se decide aleatoriamente sobre um personagem para narrar-lhe a história (história que se assemelha à de cada indivíduo da multidão)" (SANT’ANNA, 2005, p. 217).

A referência ao famoso filme do cinema italiano exprime, na crítica de Sant'Anna, um procedimento comum ao cânon do movimento cinematográfico neorrealista, o qual se manifesta no filme de João Batista, de acordo com o crítico, numa construção "mediante uma pormenorizada articulação de situações, que identificam os personagens por traços comuns de similaridade e reificação" (idem, p. 216). Deraldo e Severino não são unicamente sósias, mas também nordestinos, conterrâneos até cujos nomes se confundem. Uma veemente intenção em salientar os traços de uma similaridade que confunde rostos e nomes de tantas pessoas com história comum atravessa todo o filme, expressando-se em frases recorrentes como: "Tudo esses pau-de-arara é Silva", na mencionada voz do policial; ou, então, quando perguntado por um operário se é cearense ou alagoano, diz o personagem que é paraibano, ao que lhe responde e sentencia o outro: "É tudo a mesma coisa"; ou ainda, quando ouve, em diferentes momentos, perguntas ou comentários sobre a familiaridade de seu rosto: "Escuta, eu não vi tua cara em algum lugar já não?”, ou “Eu já vi essa cara em algum lugar”.

Rostos e nomes assim tão insistentemente confundidos no filme são significativos como expressão da questão da identidade problematizada na obra, pois questiona justamente os estereótipos que engessam a figura do imigrante numa imagem 
imobilizadora, petrificada, reproduzida. Tal como podemos ver, pelo jogo do duplo urdido no filme, Deraldo em José Severino, e vice-versa, assim também Deraldo se vê na figura de Antônio Virgulino, uma outra imagem especular que aparece num momento fundamental de $O$ Homem que virou suco. É o momento em que o personagem chega às obras de um metrô em construção, após uma trajetória de experiências frustradas de trabalho, quando deve passar por uma espécie de curso na fase de preparação dos operários para as atividades, uma aula em que é impingido a ele e a seus colegas um audiovisual agressivo que ridiculariza elementos do universo cultural do imigrante nordestino, mão-de-obra ali abundante. A evidente alusão à figura mítica de Virgulino Ferreira da Silva, o Lampião, - encarnada no personagem de Antônio Virgulino da Silva, que protagoniza a história do audiovisual -, tão grotescamente escarnecida, é insuportável para Deraldo, que se vê, agora, nesse outro personagem, mais um Silva como ele e José Severino.

Nessa ficção dentro da ficção, temos mais uma história que cruza com a de Deraldo: assim como o poeta, Antônio Virgulino é um conterrâneo que acaba indo para a grande cidade, rebelde que também se insurge, assim como Deraldo em todo o seu percurso, contra situações que o humilham e oprimem. A perturbação de Deraldo é o intolerável da zombaria à imagem refletida, uma imagem especular, nesse caso, na função cristal que realiza a condição metalinguística da obra dentro da obra: nessa condição, como observa Deleuze, "é o filme que se reflete numa peça de teatro, num espetáculo, num quadro ou, melhor, num filme no interior do filme" (2007, p. 96), como na breve narrativa da história de Antônio Virgulino, na qual enxergamos uma projeção do drama de Deraldo. A aproximação entre os personagens é tecida, na construção fílmica, pela montagem que faz alternar os slides do audiovisual com close-ups dos operários que participam do curso preparatório, detendo-se sobretudo sobre o rosto de Deraldo, fazendo o áudio incidir ora sobre um, ora sobre o outro, como se falasse da mesma pessoa. E, do mesmo modo como um personagem se projeta sobre o outro, também o audiovisual, imagem especular, projeta-se sobre o filme, urdindo relações pelas quais podemos ver um refletido no outro. Vários elementos do universo cultural nordestino se exprimem por meio das músicas, dos mitos, das vaquejadas, aludindo ao meio de onde saíram Deraldo e José Severino, elementos estranhos naquele novo espaço, cujo conflito resultante dessa condição é retratado na história narrada pelo audiovisual. Particularmente importante, nesse sentido, é a imagem de um homem insubmisso, que não apenas se recusava a trabalhar, como, ademais, também fazia pirraça, desrespeitava as ordens, desafiava o chefe, segundo o narrador em off da projeção. E assim, embora manifestasse, a princípio, tão somente certa tensão, Deraldo logo fica muito incomodado, bastante atingido pela maneira como são depreciados aspectos de sua cultura, afetado como se visse a si na imagem de Antônio Virgulino.

Com efeito, numa das sequências seguintes, Deraldo aparece, então, numa esquina movimentada de São Paulo - no cruzamento da Ipiranga com a São João -, apoiado a um poste, trajado da cabeça aos pés como um cangaceiro, armado de fuzil, facão e cartucheiras cruzadas a tiracolo e na cintura. Ele aparece como Antônio Virgulino, vestido como ele e atirando - como relata o locutor em off - "uma grossa cusparada", ameaçando com sua peixeira ao círculo de pessoas que se forma à sua volta. São 
imagens atormentadas de pesadelo, as quais refletem a experiência inquietadora do curso de preparação, momento em que o personagem percebe mais profundamente os mecanismos das forças que procuram dominá-lo, algo como a culminância de toda opressão que marca seu caminho, quando se lhe revelam as capturas do poder numa dimensão menos material, mais num nível subjetivo, que procuram sujeitar o indivíduo, - momento em que, após ter sentido em seu próprio corpo e consciência tudo quanto o explora e o oprime, ele poderá entender o que ocorreu a José Severino e escrever, enfim, a história deste "homem que virou suco".

De fato, é significativo que tão-somente após todo um percurso marcado por várias tentativas malogradas de trabalho, humilhações e exploração, o personagem decida, finalmente, sair em busca de José Severino, a fim de resolver o problema a que fora lançado pela confusão de seus rostos. Como se Deraldo tivesse, antes, que virar Severino para assim encontrar o seu duplo, isto é, como se tivesse que passar, de poeta a operário, por condição semelhante à do sósia, e atravessar, desse modo, consoante a metáfora do filme, um processo metamórfico que o faz virar suco, virar bicho, virar outro. É somente então que Deraldo faz esse caminho à procura de José Severino e descobre, pois, as razões que o levaram a matar o patrão, transformando em matéria de sua arte a história de um homem explorado ao limite: um operário modelar que, empenhado num resoluto interesse em ascender, dera tudo quanto pôde à empresa, indispondo-se com os próprios colegas, entregando inclusive líderes grevistas - o que o acabou perdendo, já que, traídos, seus colegas operários decidiram suspender o trabalho na sua presença, resultando na sua demissão. Tendo se sujeitado até a culminância de tudo o que pudera dar à empresa, depois de tão esmagado e exaurido de toda sua substância, quando não restava mais do que um corpo esbagaçado, é refugado então como rebotalho descartável.

É esse o sentido reificador para o qual chama a atenção Sant'Ana em sua crítica ao filme de João Batista, essa condição bestializante que reduz o trabalhador a uma vida vampirizada até a última gota, macerada e degradada sob as pressões da máquina capitalista até o total descarte, como exemplarmente no caso de José Severino, que, depois de demitido, assassina o patrão e enlouquece. Máquina cuja perversidade faz o homem virar bicho, tal como expresso na sequência em que Deraldo, contratado como operário para as obras no metrô, encontra-se só à entrada do refeitório, um acesso de madeira improvisado que lembra bem um corredor utilizado para controle, vacinação ou o encaminhamento ao abate de gado. Como que numa espécie de estado de transe, o personagem entra ali e avança com gestos lentos, a princípio roçando nas tábuas e, em seguida, cabeceando-as, ao mesmo tempo em que ouvimos um leve gemido, que vai se intensificando até rebentar num forte mugido. $O$ movimento moroso com que o personagem se desloca é menos de sujeito que de objeto: arrastando-se, como que absorvido por uma força que o captura, ele arqueia, com as mãos presas nas tábuas, quase que de quatro, até que, com ímpeto, atira-se para frente, chocando-se contra as pranchas, como quadrúpede que se debate. Do plano médio de que parte a câmera, vemo-lo enquadrado de perfil, em movimento lateral que o descreve, enquanto muge e marra, na metamorfose ao cabo da qual o percebemos transformado em boi, até fechá-lo num close-up sobre a cara inexpressiva, os olhos opacos, numa impressionante imagem de animal encurralado. 
O "homem-boi", besta humana de um vasto rebanho de que a máquina capitalista se serve explorando-a brutalmente, é uma imagem que remete a uma das obras clássicas do cinema soviético: em A Greve, de 1924, Eisenstein comparava já o massacre aos operários em greve de uma fábrica russa, sob o contexto do Estado czarista, a uma violenta matança bovina. Metáfora, aliás, que vem de par com uma outra em referência ao mesmo filme e que representa, na verdade, no jogo de metáforas tecido por João Batista, a ideia fundamental que motiva e intitula o filme, isto é, o sentido de "virar suco", que em $A$ Greve é expresso no momento em que os acionistas da fábrica parada discutem o que fazer. Um deles aparece espremendo um fruto e, com isso, traduz a lógica reificadora da exploração capitalista, cujos interesses em jogo determinam que se deva desfazer-se do bagaço já sem préstimo quando o sumo se tornou inconsumível.

Contudo, contra o peso dessa máquina cada vez mais insustentável, contra a opressão e as humilhações mais e mais intoleráveis, num percurso pontuado pela intensificação das situações que o levam ao limite do insuportável, Deraldo irrompe sempre mais indignado. O personagem se insurge, não para em trabalho algum, entra em conflito quase a todo momento, numa exasperação que só faz aumentar, reagindo com força redobrada - reação que rebenta como a resposta inconformada de quem sente e percebe mais profundamente a cada passo tudo quanto o captura, oprime e discrimina. Desse modo, se o personagem surge, de início, na condição da vida nua, que é precisamente aquela que faz seu caminho se encontrar com o de José Severino, o herói a supera, entretanto, no percurso que realiza. Embora atravessando espaços marcados pela miséria e a violência, Deraldo não paralisa nessa condição da vida nua severina, absorvido como vítima inelutável das injunções sociais. Pelo contrário, contra o viés vitimizante que estigmatiza a figura do imigrante nordestino, o personagem cresce no curso de sua trajetória, num caminho assinalado pela postura radical de um homem que abre uma linha de fuga como possibilidade de luta de uma resistência singular.

É significativo que num filme tão empenhado em fazer sobressair a presença das classes - escancarando o abismo que as separa e as relações que as colocam em choque -, o herói seja, na verdade, uma figura solitária de resistência. Com efeito, é revelador que esse poeta popular, para quem a classe operária constitui o público e a matéria de sua arte, não consiga em momento algum inserir-se nela, apesar de suas reiteradas tentativas. Contrariando o encaminhamento presumível que se poderia esperar num filme movimentado pela dialética do embate de classes, Deraldo não toma parte em nenhuma greve, não se mobiliza para nenhuma forma de luta coletiva, e seu folheto está longe de se colocar como instrumento para a luta de classe: do começo ao fim, sua resistência é totalmente singular, a potencialidade despertada na vida de um homem singular, a afirmação, segundo Agamben, do caráter potencial que é da natureza ontológica mesma de toda singularidade qualquer.

Ora, como observa o filósofo italiano, no contexto contemporâneo, as forças que se insubordinam e mais ameaçam o biopoder não mais irromperiam de organizações associativas de indivíduos, como outrora, mas sobretudo das ações de singularidades, a ação de um ser qualquer que pode confrontar o Estado, como aquele homem que, nos eventos de Maio em Pequim, desafiou a violência do governo chinês diante de um tanque na Praça Tienanmen. O “ser que vem”, diz Agamben (1993), é o "ser qualquer"; 
não o qualquer ser, o qualquer um que subsumisse a singularidade à indiferenciação pela propriedade compartilhada num conjunto, mas o ser qualquer, que não é nem universal, nem individual, que não apresenta condição alguma de pertença, mas que também não se reduz ao particular. Privada de qualquer identidade que possa reconhecer, refutando toda condição de pertencimento, as singularidades representam o maior perigo ao poder estatal justamente porque o Estado, para que possa capturar os indivíduos, precisa que estes assumam e sejam identificados; o que, pelo contrário, o Estado não pode admitir de modo algum é precisamente que as singularidades formem comunidade sem a fundamentarem numa identidade representável.

Contra as propostas comunitárias que, a exemplo das sociedades socialistas, ignoraram e/ou produziram violência sobre as singularidades, Agamben propõe pensar uma comunidade sem essência, não pressuposta, que não se fundamente em nenhum laço identitário, conceito ou propriedade - a comunidade das singularidades quaisquer. Uma comunidade que, porquanto constituída na impropriedade, eximiria as singularidades de qualquer papel numa suposta obra comum que devessem assumir. Sem destino histórico algum a cumprir, assim como tampouco qualquer origem que se lhe atribuiria o dever de preservar ou resgatar, às singularidades não estaria reservada nenhuma tarefa que lhes competisse realizar, restando completamente isentas de qualquer coisa que se lhes imponha a não ser única e exclusivamente aquilo que toda singularidade é e tem de ser: "o simples facto da sua própria existência como possibilidade ou potência" (AGAMBEN, 1993, p. 38).

Certamente, nenhum poder é capaz de se impor unilateralmente de cima para baixo sem que se lhe oponha movimento algum de contrapoder. Mesmo no caminho solitário de um homem como Deraldo, sob todo o fardo de tudo quanto o oprime, o personagem não se imobiliza condenado à condição da vida nua severina. Pelo contrário, na negativa intransigente com que o personagem responde insubmisso a toda e qualquer situação em que se sente explorado ou humilhado manifesta-se, na sua forma mais radical, aquele caráter potencial que, conforme Agamben, tem sempre o ser qualquer. De fato, o não irredutível de Deraldo nos faz lembrar a figura de Bartleby, o famoso personagem de Herman Melville, escrivão que a todas as ordens e pedidos que lhe eram dirigidos respondia sempre não, que "preferiria não" fazer. Bartleby encarna, para Agamben, a expressão maior da natureza potencial da singularidade qualquer: sua "potência de não ser" - por oposição, na distinção aristotélica, à "potência de ser" -, uma potência suprema, de acordo com o filósofo italiano, já que tanto pode a potência como a própria impotência. Bartleby é o rasum tabulae de que fala Aristóteles em De anima, a tábua de escrever na qual nada está escrito e que representa, portanto, a pura potência do pensamento, que não é tão-somente a "potência de pensar este ou aquele inteligível", desaparecendo, assim, desde logo no ato, mas que é "também potência de não pensar” (AGAMBEN, 1993, p. 34). Ele representa, desse modo, a política da passividade de que fala o autor e que constitui o horizonte político da singularidade qualquer. Um ser passivo que não deve ser confundido, porém, com o ser alienado e conformado, já que Bartleby não é uma figura simplesmente passiva; é ele quem "escreve a sua própria passividade", sujeito em sua potência do não, potência que se volta para si, que pensa a si mesma. 
O não inabalável do personagem de Melville revela-se como um forte gesto de resistência, levando-o ao extremo de sua morte, uma postura radical que desconcerta e põe em xeque qualquer forma de controle, qualquer mecanismo de exploração. Um gesto que se reflete também, a nosso ver, na postura do personagem de $O$ Homem que virou suco, que se rebela a todo o instante contra toda e qualquer força que procure dominá-lo, capturá-lo, num percurso assinalado do começo ao fim por embates que não o permitem parar em emprego algum, que o fazem explodir e brigar, questionar e oporse sempre, num crescendo exasperador. Sua postura é também a de um não intransigente, que não o leva, no entanto, ao mesmo fim de Bartleby, mas que, por mantê-lo fora das relações de trabalho, em movimento constante de fuga, acaba lançando-o a uma condição marginal, fazendo-o perambular, num deslocamento que responde - com que reage - a tudo o que o desloca à margem.

Num retrato contundente dessa condição que rebaixa Deraldo e toda aquela multidão de imigrantes marginalizada na capital paulista, apartada num território de exclusão, a sequencia noturna da perseguição a Deraldo pelo morro, após a abordagem dos policiais que o tomam pelo operário assassino, é expressiva da violência que pode assaltá-los arbitrariamente da noite para o dia. Acuado, o personagem foge, desaparecendo sob a escuridão da noite, enquanto o carro policial sai em seu encalço. No caminho pelo qual acossam o fugitivo, os policiais apontam a luz de um holofote pelo espaço que percorrem, revelando-o pelos detalhes sob o foco do refletor, onde vemos emergir, então, vários elementos de um universo segregado: fachadas de casebres bastante precários, alguns dos quais invadidos pela polícia, becos minguados de luz, pessoas que passam e rostos - muitos rostos, em grande parte enquadrados frontalmente, contraídos pela forte incidência da luz. Ouvimos, de vez em quando, o som indiscernível de rádio policial, o que nos situa no interior da viatura, de onde parte o foco de luz e que representa a perspectiva sob a qual entramos naquele espaço, invadindo, pois, sob a luz da repressão da polícia, um lugar do qual tomamos conhecimento principalmente a partir das notícias que nos chegam sobre a violência que parece marcar o seu quotidiano. Assim, na noite cerrada, contra o fundo densamente escuro, o facho que o ilumina em detalhe vai nos descerrando, como que pelo olho repressor que o devassa, aspectos de uma realidade miserável, e o que vemos, aquilo que mais nos atinge, enquanto a música de Vital Farias, Bate com o pé xaxado, alude à Paraíba e às dificuldades que marcam as vidas de pessoas como Deraldo, são rostos severinos, expostos sob os traços engessados da condição que os estigmatiza, exibidos sob o clarão do projetor que os invade, sinal da violência policial.

Naquele território de abandono onde vivem no ostracismo, estão todos rebaixados, pois, à vida nua - vida tão despojada, desabrigada de qualquer direito, que tanto faz, ao poder, que persista ou morra -, a vida severina de todos aqueles imigrantes discriminados sob um violento apartheid velado, cujo estigma que os diferencia delineia-se nos traços do rosto que os define. Em meio a toda aquela massa de deserdados, Deraldo, "cara de severino" - isto é, reconhecido nos traços não-conformes que o identificam por suas feições severinas -, é fatalmente confundido com José Severino da Silva, assim como poderia igualmente ter sido confundido com qualquer um daquele aglomerado de tantos homens marcados pelas estereotipadas linhas que lhes dão um rosto comum. Na contracorrente, porém, dessa imagem estigmatizante - que, de 
resto, acabou se cristalizando nas telas da televisão e do cinema num olhar que enquadra a figura do imigrante numa moldura miserabilista, vitimizante -, o personagem de $O$ Homem que virou suco coloca em questão os contornos desse retrato despotencializador no movimento pelo qual foge às capturas que procuram aprisioná-lo e reduzi-lo ao qualquer rosto severino.

O percurso de Deraldo não descreve uma trajetória progressiva, ele não realiza uma evolução linear; pelo contrário, seu caminho é desviante, o personagem perambula. Como lembra Deleuze (2007), ao lado dos videntes, os que perambulam são personagens fundamentais do cinema moderno, eles proliferam a partir do Neorrealismo italiano, presentes pela expressão política que encarnam e que então passa a interessar aos cineastas. Afinal, são figuras de resistência, personagens que traçam no seu deslocamento errático linhas de fuga, a potência irreprimível de singulares que escapam, com suas esquivas, às capturas do poder. Assim, se o filme de João Batista expõe o funcionamento de uma máquina reificadora que explora, oprime e procura liquefazer o indivíduo, não vemos Deraldo, porém, premido, sucumbir à direção de um sentido imposto como fio de caldo que fosse conduzido numa superfície estriada; pelo contrário, - conforme a distinção proposta por Deleuze e Guattari -, é numa superfície lisa que se move o personagem, no seu deslocamento oblíquo, na fuga aos sulcos de um sentido fixo e determinado. Como o esquizo, como o nômade incapturável, Deraldo, portanto, é a figura do solitário errante que escapa a todas as formas de opressão, homem que se insurge contra tudo quanto procura esmagá-lo e humilhá-lo, resistência radical - como a figura de Bartleby - de um não resoluto e irredutível, expressão, enfim, da potencialidade de um homem singular qualquer. Personagem que desfaz, desse modo, os traços estigmatizantes que o remetem ao qualquer rosto severino, que afirma contra aquele traçado duro que o define e encerra nesse rosto - a singularidade de um homem ordinário, as linhas de expressão de um rosto singular qualquer.

\section{REFERÊNCIAS}

AGAMBEN, Giorgio. A Comunidade que vem. Lisboa: Editorial Presença, 1993.

Homo sacer: o poder soberano e a vida nua I. Tradução de: BURIGO, Henrique. 2. ed. Belo Horizonte: UFMG, 2010.

BERNARDET, Jean-Claude. Cineastas e imagens do povo. São Paulo: Companhia das Letras, 2003. DELEUZE, Gilles. A imagem-tempo: cinema 2. Tradução de: RIBEIRO, Eloisa de Araujo. São Paulo: Brasiliense, 2007.

; GUATTARI, Félix. Ano zero - rostidade. In: Mil platôs: capitalismo e esquizofrenia 3. Tradução de: OLIVEIRA, Ana Lúcia de; LEÃO, Lúcia Cláudia. São Paulo: Editora 34, 2007.

GUIMARÃES, César. Comum, ordinário, popular: figuras da alteridade no documentário brasileiro contemporâneo. In: MIGLIORIN, Cezar (org.). Ensaios no real. Rio de Janeiro: Beco do Azougue, 2010. MELO NETO, João Cabral de. Morte e vida severina. Rio de Janeiro: Objetiva, 2007.

O HOMEM que virou suco. Roteiro e direção de João Batista de Andrade. Produção de Assunção Hernandes. São Paulo: Embrafilme/Secretaria de Cultura do Estado de São Paulo, 1979. 1 DVD (90 min.), son., color.

SANT'ANNA, Romildo. Cinema verdade: o homem que virou suco. In: ABDALLAH, Ariane; CANNITO, Newton (org.). O Homem que virou suco: roteiro do filme, fortuna crítica, depoimentos e entrevistas. São Paulo: Imprensa Oficial do Estado de São Paulo; Fundação Padre Anchieta, 2005. (Coleção Aplauso. Série Cinema Brasil). 
Recebido em 05/10/2015. Aprovado em 10/11/2015.

Title: The politics of "rosto Severino" in O homem que virou suco, by João Batista de Andrade

Abstract: This paper aims to analyze João Batista de Andrade's O Homem que virou suco (1979) from a political perspective that seeks to problematize the crystalized stereotypical image of the migrant from the Northeast of Brazil as historically stigmatized in our audiovisual culture. The focus is on the politics of the face as a means to empower the image of the migrant and potencialize their otherwise victimizing portrayal.

Keywords: Face. Stereotype. Brazilian cinema. Migrant. 